\title{
A glomus vagale tumorok kivizsgálása és ellátása
}

\author{
Iszlai Zoltán dr. ${ }^{1}$ - Szövördi Éva dr. ${ }^{2}$ - Karosi Tamás dr. ${ }^{1}$ \\ ${ }^{1}$ Borsod-Abaúj-Zemplén Megyei Központi Kórház és Egyetemi Oktató Kórház, \\ Fül-Orr-Gégészeti és Fej-Nyaksebészeti Osztály, Miskolc \\ ${ }^{2}$ Borsod-Abaúj-Zemplén Megyei Központi Kórház és Egyetemi Oktató Kórház, Pathologiai Osztály, Miskolc
}

\begin{abstract}
Esetbemutatásunkban a világviszonylatban is ritkának számító glomus vagale tumorok kivizsgálásáról, terápiájáról adunk összefogó képet. A jellemzően középkorú nőket érintő betegség unilaterálisan elhelyezkedő nyaki tumoros elváltozás képében jelenik meg, melyre nem minden esetben jellemző a felette érezhető pulzáció (Fontaine-jel), a glomus caroticum tumorokkal szemben. Nagy hangsúlyt fektetve a fül-orr-gégészeti fizikális vizsgálatra, a betegség pontos diagnózisát a CT-angiográfia adja meg. Figyelembe véve a kiterjedést, a szomszédos erekhez, idegekhez, izmokhoz, illetve csontszerkezetű képletekhez (koponyaalap, nyaki gerinc) való viszonyt, az esetek nagy részében sebészi beavatkozás mellett döntünk. A bemutatott beteg kezelése 2017 szeptemberében történt Osztályunkon.

Orv Hetil. 2019; 160(34): 1358-1362.
\end{abstract}

Kulcsszavak: digitális szubtrakciós angiográfia, glomus vagale, chemodectoma, a nervus vagus tumora

\section{Tumors of glomus vagale: diagnostics and therapy}

Introducing the diagnostic protocol and therapy of a rare disease reviewing the worldwide literature named as vagal paraganglioma is our main target. This type is specific for women of middle age, and it is appearing as a unilateral neck mass, with or without Fontaine's sign. Giving a heavy aspect on the ear, nose and throat examination, the most important diagnostic tool is CT-angiography. Carefully looking at the size and relationship with the narrowing arteries, veins, nerves, muscles and bony structures (skull base, cervical spine), in most of the cases we choose the surgical procedure.

Keywords: digital subtraction angiography, glomus vagale, chemodectoma, vagal's nerve tumor

Iszlai Z, Szövördi É, Karosi T. [Tumors of glomus vagale: diagnostics and therapy]. Orv Hetil. 2019; 160(34): 1358-1362.

(Beérkezett: 2019. január 30., elfogadva: 2019. április 22.)

\begin{abstract}
Rövidítések
$\mathrm{ACC}=$ arteria carotis communis; $\mathrm{ACE}=$ arteria carotis externa; $\mathrm{ACI}=$ arteria carotis interna; $\mathrm{CBT}=($ carotid body tumor $) \mathrm{a}$ glomus caroticum paragangliomája; $\mathrm{CT}=($ computed tomography) komputertomográfia; DSA $=($ digital subtraction angiography) digitális szubtrakciós angiográfia; ENT = (ear, nose and throat) fül-orr-gégészet; GAD $=$ (generalized anxiety disorder) generalizált szorongásos zavar; $\mathrm{MR}=$ (magnetic resonance) mágneses rezonancia; $\mathrm{MRI}=$ (magnetic resonance imaging) mágnesesrezonancia-képalkotás; PDGF = (platelet derived growth factor) vérlemezkéből származó növekedési faktor; PVA = poli-vinil-alkohol; SDH = szukcinát-dehidro-
\end{abstract}

genáz; SMA = (spinal muscular atrophy $)$ spinalis izomatrófia; $\mathrm{UH}=$ ultrahang; VEGF $=$ (vascular endothelial growth factor $)$ vascularis endothelialis növekedési faktor

A 61 éves nőbeteget 1998-ban Basedow-kórral diagnosztizálták; kezelése folytonos, endokrinológiailag tünetmentes. Coderit (kodein-hidroklorid)-érzékenységgel rendelkező páciensünk ASA Protect (aszpirin) 100 mg-os, illetve Letrox (levotiroxin) $25 \mu \mathrm{g}$-os kezelésben részesült. Perzisztáló szédüléses panaszai miatt kereste 
fel fül-orr-gégészeti és fej-nyaksebészeti ambulanciánkat, ahol általános fül-orr-gégészeti vizsgálata következett. A fenti kivizsgálás során a nyak jobb oldalán kb. $20 \times 20$ mm-es pulzáló rezisztencia mutatkozott; hallgatózáskor a képlet fölött surrogás volt hallható, tapintásra enyhe pulzációt észleltünk (Fontaine-jel).

A fentieket figyelembe véve, nyaki MRI mellett foglaltunk állást, melynek során egy $20 \mathrm{~mm}$-es, a carotis interna szintjén elhelyezkedő, jól vascularisalt tumort írtak le.

Többnapos premedikációt követően CT-angiográfia, illetve DSA következett. Az előzőleg leírt 20 mm-es képlet vascularisatióját az ACE pharyngea ascendens ága adta (1. ábra).

DSA során a jobb oldali femoralis punkción keresztül az azonos oldali ACE-n áthaladva az arteria (a.) pharyn-

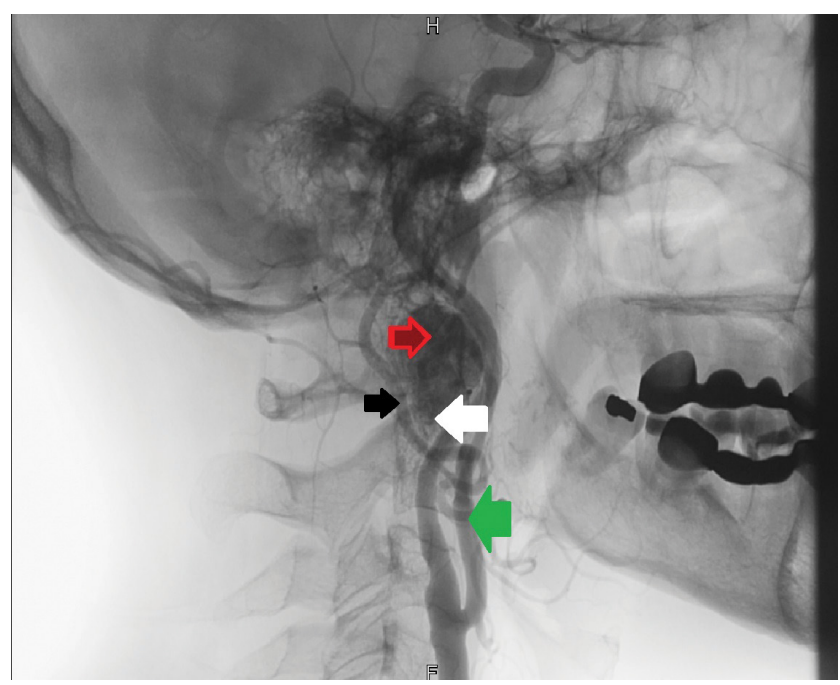

1. ábra

Megfigyelhető a tumor (piros nyíl), illetve annak vascularisatiója a vascularis ágyával (fehér nyíl), az a. carotis externa (zöld nyíl), illetve az a. pharyngea ascendens (fekete nyíl)

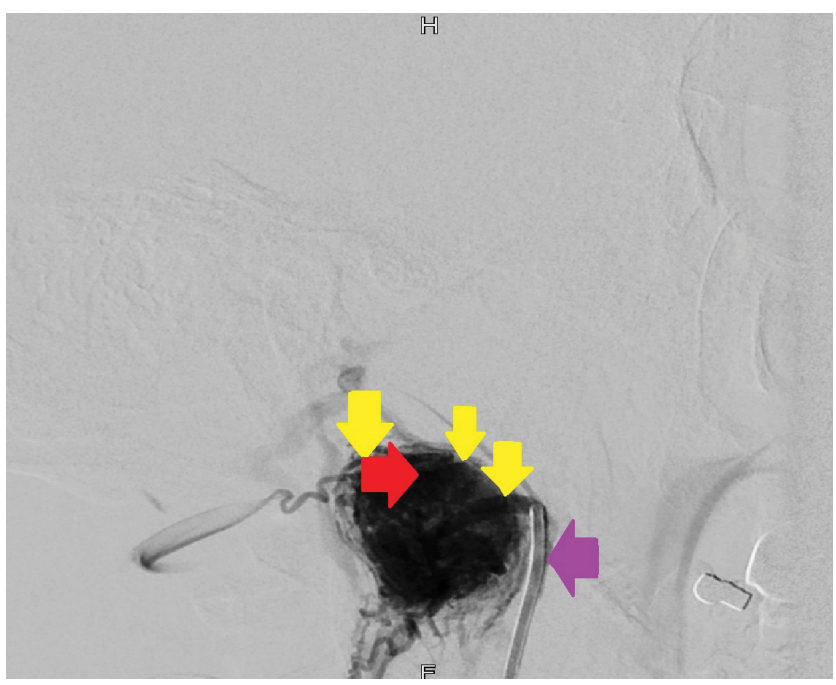

2. ábra A tumor (piros nyíl), a katétervég PVA-szemcsék injektálása
után (lila nyíl), illetve a kialakult avascularis állapot (sárga nyilak)
PVA = poli-vinil-alkohol

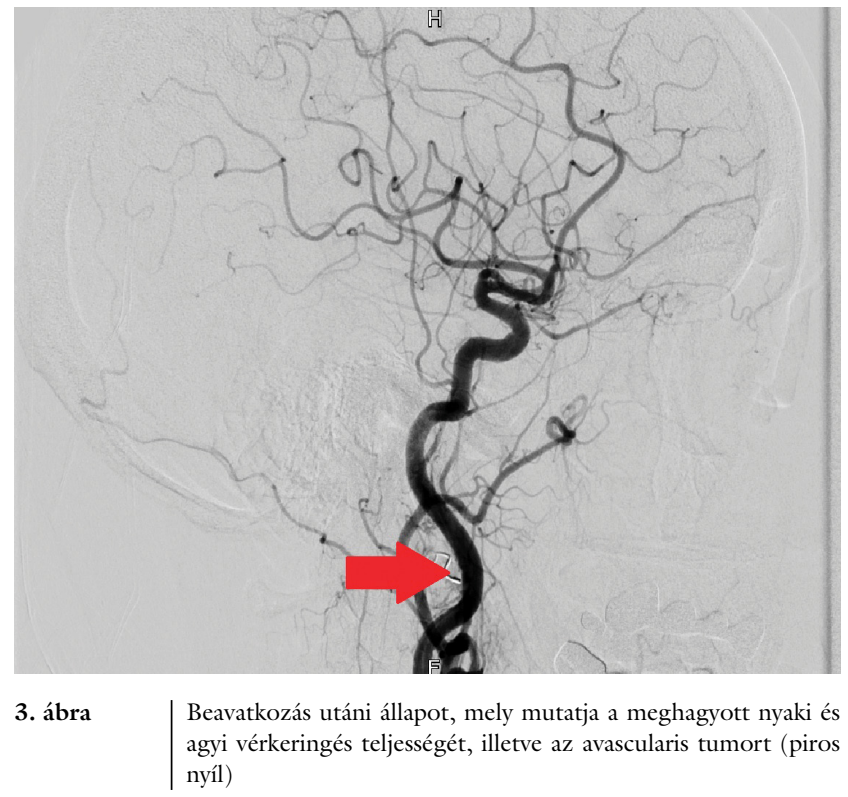

gea ascendensból leágazó vaskos afferens, a tumort ellátó artériába 0,25 ampulla 710-1000 mikronos PVA-szemcsék injektálása történt, amit egy 'fibered coil' (fonalas tekercs) visszahagyása követett (2. ábra). DSA utáni állapotban a teljes nyaki, illetve agyi vérkeringés megmaradt. A beavatkozás során a tumor vascularis ágya, illetve annak keringése szubtotális mértékben lecsökkent, az ACI felől telődés nem volt megfigyelhető (3. ábra).

\section{Mütét}

Az endovascularis beavatkozást követően - tekintettel a beteg kielégítő statusára, életkorára, a tumor avascularis közeli állapotára - intravénás antibiotikumvédelemben

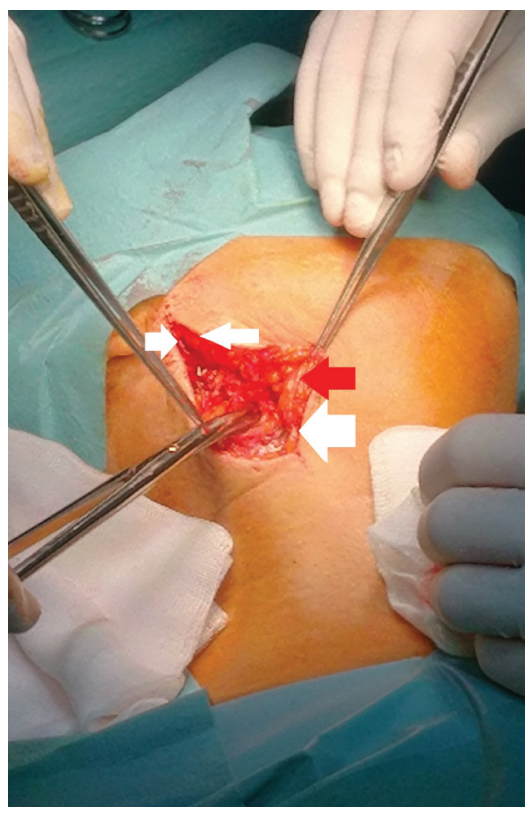

4. ábra

Látható a sebészi metszés helyzete (fehér nyíl), illetve a felszínes nyaki fascia kiemelve (piros nyíl) 


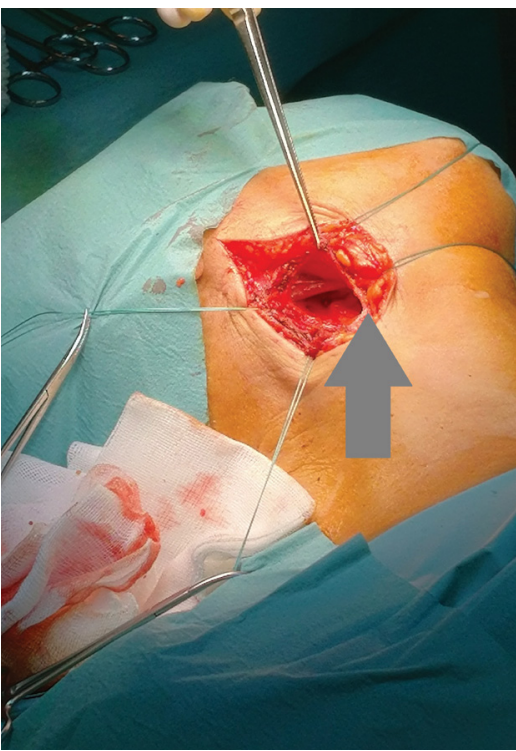

5. ábra Megtörténik a sebszélek rögzítése, illetve az a. carotis externa
fölött elhelyezkedő behatolási terület is megfigyelhető (szürke
nyíl)

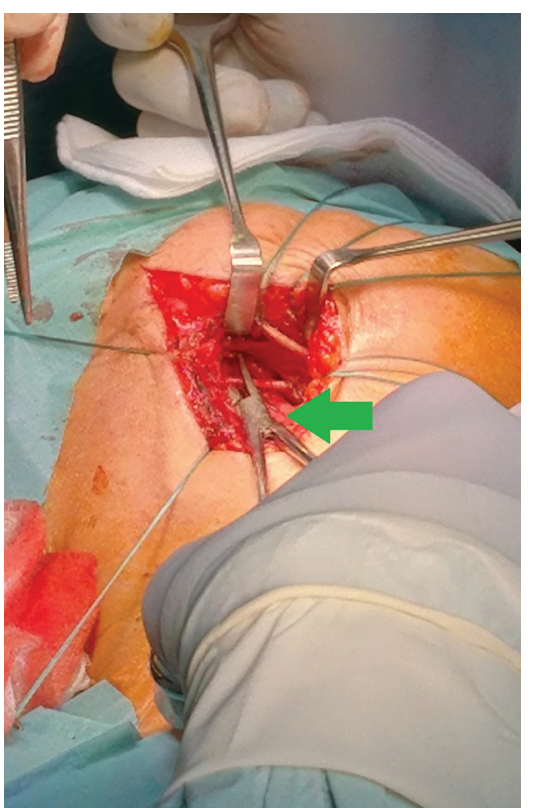

6. ábra

Az a. carotis externa, illetve a canalis vasovagorum kipreparálása (zöld nyíl). Cranial irányba történő haladás

(3 × 1,2 g amoxicillin-klavulánsav 5 napig) a 7 . napon végzendő teljes sebészi eltávolítás mellett foglaltunk állást.

Intratrachealis narkózisban történő mütétünk során a jobb oldali fejbiccentő izom elülső szélének megfelelően egy $8 \mathrm{~cm}$-es metszést ejtettünk, majd a felszínes nyaki fasciát átmetszve a fejbiccentő izom elkampózásra került (4. ábra). A kialakított sebszélek rögzítésre kerültek, majd a külső nyaki verőér fölötti területet kaptuk (5. ábra). Azonosítva az ACE-t, illetve a szomszédos nervus (n.) vagust, cranial felé haladva az ebből kiinduló tumoros elváltozás került a mütéti látotérbe; az ezt ellátó vaskos a. pharyngea ascendensből a DSA során visszaha-

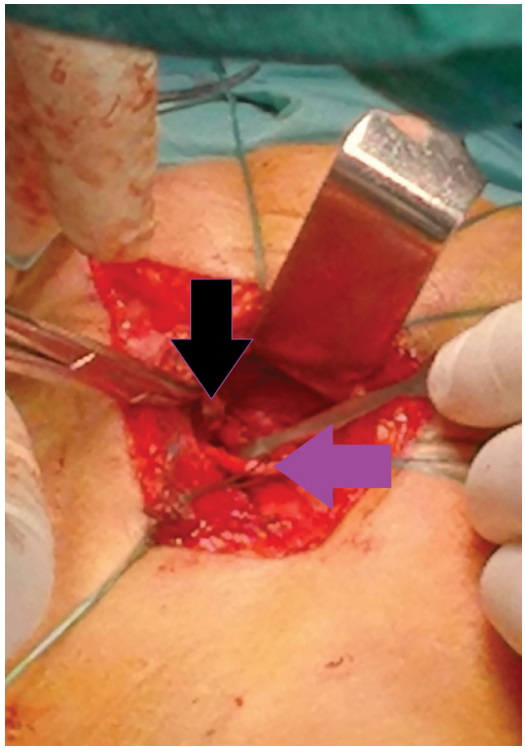

7. ábra

Az a. pharyngea ascendens eltartva (lila nyíl), a kipreparált tumor (fekete nyíl)

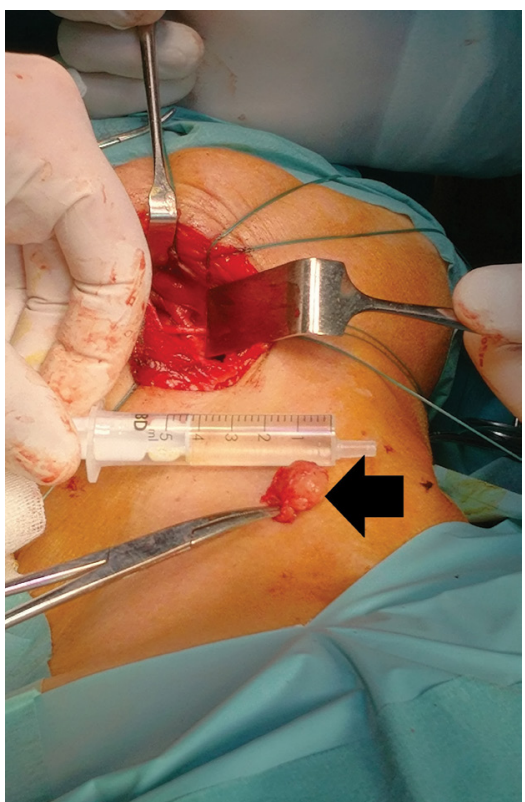

8. ábra

Teljes eltávolítást követően a preparátum (fekete nyíl) mérése látható, mely pontosan $2 \mathrm{~cm}$

gyott fonalas tekercset eltávolítottuk, majd a leírt képletet lekötöttük (6. ábra). Az ellátó mikroerek lekötését követően a n. vagusból kinduló tumoros képlet azonosítása következett (7. ábra). Az eltávolított tumor nagysága 2 $\mathrm{cm}$ volt (8. ábra). Vérzéscsillapítást követően a sebalapba szívódrént helyeztünk, majd a sebszéleket réteg szerint egyesítettük. A sebfelszínre fedőkötést helyeztünk, a nyomókötést nem tartottuk szükségesnek.

Mindennapos kötéscsere, illetve a dréneltávolítás után a beteg folytonos antibiotikumvédelem, illetve zavartalanul gyógyuló sebszélek mellett jó általános állapotban távozott otthonába. 


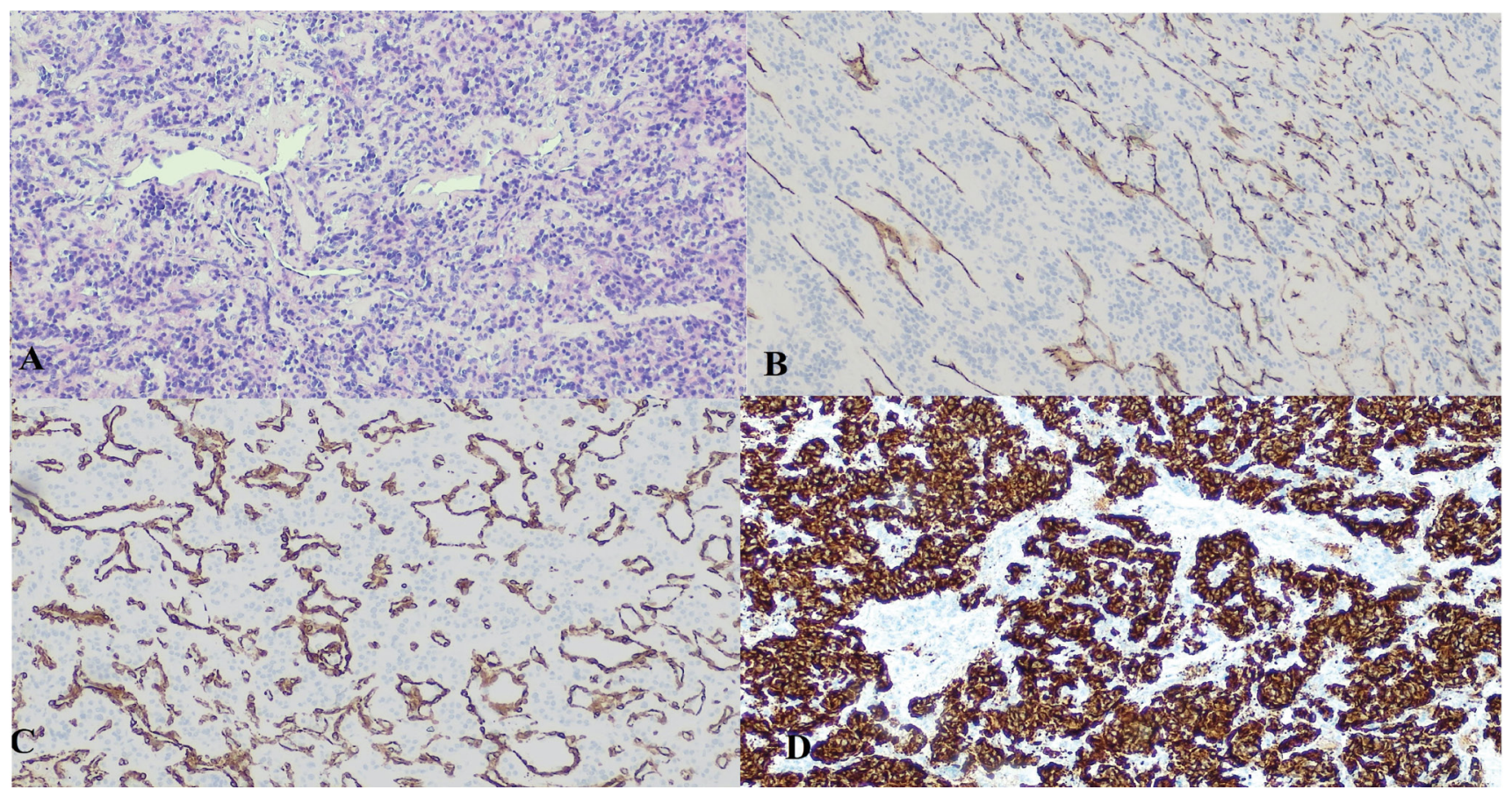

9. ábra

A) Látható a fészkes, trabecularis szerkezetû glomussejt-proliferáció, relatíve monomorf sejtképpel, bőségesen vascularisalt stromával. B) A CD34 a vasculaturának megfelelően mutat pozitivitást. C) A SMA a vasculaturának megfelelően mutat pozitivitást. D) Megfigyelhető a glomussejtek intenzív szinaptofizinpozitivitása

A fenti mútét a következő linken tekinthetó meg: https://www.youtube.com/watch?v= QMRbUhoAmaI$\& \mathrm{t}=17 \mathrm{~s}$

\section{Szövettan}

Pontos szövettani eredményt a 3. hét során kaptunk, melynek diagnózisa paragangliomát eredményezett. $\mathrm{He}$ matoxilin-eozin festés során jól megfigyelhetô volt a böséges vascularisalt stroma. Továbbá SMA-, CD34-, S100- és szinaptofizinpozitivitás is rögzítésre került (9. ábra).

\section{Megbeszélés}

A n. vagus, illetve a vena (v.) jugularis interna paragangliomái azon ritka tumorok csoportjába tartoznak, melyekre jellemző az agresszív növekedés, az anatómiai elhelyezkedésük folytán létrejövő kompressziós hatás, illetve a további jellemzőjükből adódó infiltráció, mely legfő́képp a környező lágyszövetekre, agyidegekre, illetve csontos struktúrákra (koponyaalap) vonatkozik. Egyharmad részük intracranialis terjedést mutat.

Egy 1310 betegről készült tanulmányban csupán 226 esetben $(17,26 \%)$ diagnosztizáltak glomus vagalét, 1084 esetben $(82,74 \%)$ tympanojugularis paraganglioma került felfedezésre, tehát a glomus vagale megjelenési esélye a jugularis paragangliomákkal szemben 4-szer kisebb.

Mind a mai napig a sebészi beavatkozás jelenti a legbiztosabb módszert a teljes eltávolítás irányába, ellenben a tumor gazdag vérellátása komoly komplikációkhoz ve- zethet, melyek közé soroljuk a kompressziós hatás során kialakuló vénás visszafolyási elégtelenséget (v. jugularis interna), illetve az agyi hipoperfúziót (a. carotis interna).

Mindazonáltal megemlítendő, hogy konvencionális sugárterápia, külső frakcionált dózisú sugárterápia, illetve ezek kombinációja javasolt olyan betegeknél, akik vonatkozásában nem beszélhetünk sebészi beavatkozásról általános állapotrosszabbodás, előrehaladott stádium, kor, társbetegségek vagy inkomplett tumorreszekció miatt. Mivel a finomtú-biopszia abszolút kontraindikált, terápiás döntéshozatal kizárólag klinikailag lehetséges. Fontos kiemelni, hogy a sugárterápia célja a tumor növekedésének megállítása, méretének csökkentése, mintsem ennek teljes eltüntetése. Elfogadott tény, hogy tüneteket okozó, nem kétoldali, agyidegi bénulást nem kiváltó, intracranialisan terjedő tumorokat sebészi beavatkozásnak vetünk alá legfőképp akkor, ha a beteg a 40. életévét nem töltötte be [1].

A paragangliomák kialakulása az autonóm idegrendszer neuroendokrin sejtjeihez köthető. Megjelenésük testszerte jellemző, a legnagyobb számban a mellékvesekéreg medullájának szintjén jelenhetnek meg. Fej-nyaki paragangliomák kialakulását a nagy nyaki verőér, a nagy nyaki gyújtőór, illetve a n. vagus szövettani struktúráihoz köthetjük. Ezen struktúrák baroreceptorok, melyek funkciója a vérnyomás, illetve a szívfrekvencia szabályozása az általuk kialakított homeosztatikus mechanizmus révén [2].

Mivel a carotisoszlás, illetve a foramen jugulare között helyezkednek el, tulajdonságaik hasonlóak a paragangli- 
1. táblázat |A fej-nyaki paragangliomák stádiumbesorolása

\begin{tabular}{ll}
\hline Stádium & Leírás \\
\hline I. & $\begin{array}{l}\text { A parapharyngealis térben elhelyezkedő tumor, mely a } \\
\text { foramen jugularét nem fogja be. }\end{array}$ \\
II. & $\begin{array}{l}\text { A foramen jugularét befogó tumor, mely csontdestruk- } \\
\text { ciót nem okoz. }\end{array}$ \\
III. & $\begin{array}{l}\text { Tumor, mely mélyen befogja a foramen jugularét és a } \\
\text { középfület, esetenként befogva a canalis carotist. }\end{array}$ \\
\hline
\end{tabular}

omákéhoz. Méret, illetve kiterjedés szerint besorolásuk stádiumokba történik (1. táblázat) [3].

Létrejöttük 10-15\%-ban a szukcinát-dehidrogenáz (SDH) génjeinek mutációjával magyarázható, melyek jellemzően jóindulatú tumorok, növekedésük lassú $[4,5]$.

Nagyfokú érellátásukat magyarázza a különböző növekedési faktorok jelenléte, fokozott expressziója, többek között a VEGF és a PDGF. 5-15\%-uk malignizálódhat, noha primer szövettani megjelenésükben ez nem mutatkozik. Sok esetben a regionális nyirokcsomók metasztázisa utal a folyamat jellegére [6].

Hormonszekréciójuk nem teljesen tisztázott, legfo”képp katecholaminokat termelnek norepinefrin formájában, a dopaminszekréciót kimutatták több alkalommal glomus vagale esetén [7]. Fontos kiemelni, hogy betegünk generalizált szorongásos zavarban (GAD, generalized anxiety disorder) szenvedett, mely a mútétet követően, heteken belül megszünt.

Kemoreceptív tulajdonságukból adódóan válaszolnak a vér $\mathrm{O}_{2^{-}}, \mathrm{CO}_{2^{-}}$, illetve $\mathrm{pH}$-szintjének változására, így chemodectomáknak is nevezzük őket. Fontos megemlíteni, hogy a legnagyobb malignitási állandóval a glomus vagale rendelkezik, így a diagnózis felállításában a fizikai vizsgálat mellett nagy jelentősége van az UH-nak és az MR-nek, melyek kimutatják az idegi eredetiséget, a végleges diagnózis felállításához azonban nélkülözhetetlen a szövettani eredmény $[8,9]$.

A glomus caroticum paragangliomáinak ellátásához hasonlóan itt is alapvető a DSA, az embolisatio (mely többlépcsős terápia formájában is végbemehet ACI-aneurizma esetén), majd a sebészi eltávolítás a stádiumtól függően $[10,11]$.

\section{Következtetés}

A CBT-hez viszonyított kevesebb esetszámban, mely világviszonylatban és Magyarországon is jellemző, a n. vagus nyakon elhelyezkedő tumorainak kivizsgálása, kezelése nem protokoll szerint történik.

Tekintettel a fentiekre, fontosnak tartjuk a fizikális vizsgálatra fektetett nagyobb hangsúlyt, melynek során a pulzáló nyaki teriméket szélesebb kivizsgálásnak vetjük alá; noha a Fontaine-jel hiányozhat glomus vagale esetében, a társszakmák véleménye nagymértékben hozzájárul a diagnózis felállításához.
Továbbá megemlíthetjük azt, hogy a posztoperatív gyógyulási folyamat nagymértékben függ a tumorstádiumtól, illetve a preoperatív vizsgálatok pontosságától.

Fontos kiemelni, hogy a DSA szinte minden esetben döntő mind a kivizsgálás, mind a terápia szempontjából, melyet a kiterjedést, illetve a vérellátást figyelembe véve a legtöbb esetben sebészi beavatkozás követ.

Tapasztalatunk, hogy a glomus vagale tumorok ellátása komplex, összehangolt interdiszciplináris munka formájában kell, hogy megvalósuljon, figyelembe véve a beteg általános állapotát, korát, a tumor kiterjedését, illetve a páciens életminőségének javítását is.

Anyagi támogatás: A közlemény megírása és a kapcsolódó kutatómunka anyagi támogatásban nem részesült.

Szerzôi megosztás: I. Z.: Az információk begyüjtése, feldolgozása, a kézirat megírása, mútéti asszisztencia. Sz. É.: Szövettani feldolgozás, a metszet digitalizálása. K. T.: Iránymutatás, a mütét elvégzése.

Érdekeltségek: A szerzőknek nincsenek érdekeltségeik.

\section{Irodalom}

[1] Suárez C, Rodrigo JP, Bödeker CC, et al. Jugular and vagal paragangliomas: systematic study of management with surgery and radiotherapy. Head Neck 2012; 35: 1195-1204.

[2] Somasundar P, Krouse R, Hostetter R, et al. Paragangliomas - a decade of clinical experience. J Surg Oncol. 2000; 74: 286-290.

[3] Browne DJ, Fisch U, Valavanis A. Surgical therapy of glomus vagale tumors. Skull Base Surg. 1993; 3: 182-192.

[4] Sanna M, Shin SH, De Donato G, et al. Management of complex tympanojugular paragangliomas including endovascular intervention. Laryngoscope 2011; 121: 1372-1382.

[5] Papaspyrou K, Mann WJ, Amedee RG. Management of head and neck paragangliomas: review of 120 patients. Head Neck 2009; 31: 381-387.

[6] Persky MS, Setton A, Niimi Y, et al. Combined endovascular and surgical treatment of head and neck paragangliomas - a team approach. Head Neck 2002; 24: 423-431.

[7] Levin RJ, Hamill NJ, Grenko RT, et al. Dopamine-secreting glomus vagale: a case report and histopathologic correlation. Head Neck 1998; 20: 753-757.

[8] Evans JM, Collins M. Clinically diagnosed glomus vagale tumour treated with external beam radiotherapy: a review of published reports. J Med Imaging Radiat Oncol. 2009; 52: 617621.

[9] Bhatt S, Verma P, Meena N, et al. Glomus vagale tumour, can it be diagnosed only on sonography? J Ultrasound 2017; 20: 7379.

[10] Gál K, Apanisile I, Lázár I, et al. Carotid body tumor and its treatment. A case report. [A glomus caroticum paragangliomája és ellátása.] Orv Hetil. 2018; 159: 1487-1492. [Hungarian]

[11] Oláh Cs, Czabajszki M, Lázár I. Endovascular treatment of complex vascular pathology in neck and brain region. Case report. [Komplex nyaki és agyi érpatológia endovascularis kezelése.] Orv Hetil. 2017; 158: 706-710. [Hungarian]

(Iszlai Zoltán dr., Miskolc, Szentpéteri kapu 72-76., 3526 e-mail: iszlaizoltan1@gmail.com) 